\title{
Physical seed treatment techniques may influence stand establishment and yield of wheat in delayed cropping
}

\author{
Efectos de los tratamientos físicos en semillas de trigo \\ sobre el establecimiento y producción del cultivo \\ Bahram Mirshekari ${ }^{1}$
}

\begin{abstract}
Good crop establishment and its effect on productivity is one of the major challenges in crop production. To investigate the effect of seed priming by physical techniques on stand establishment and yield of delayed wheat sowing, two experiments were conducted in Tabriz, Iran. Wheat seeds were treated with ultrasound, laser, magnetic field, gamma and beta irradiation for 3.5 and 5 min. and were sown on 17 April and 2 May, 2013-2014. All the seed priming treatments improved the coefficient of uniformity of emergence compared to non-primed seeds. Seedling vigor index responded positively and significantly to seed priming agents. There was no significant difference among laser, gamma and beta irradiations with respect to time from sowing to harvesting. Seeds primed by magnetic fields, ultrasonic waves and shorter exposure time to gamma irradiation had high chlorophyll in leaves. There was a non-significant difference between seed yields from sowing dates of 17 April and 2 May, and the yield ranged from $334 \mathrm{~g}$ $\mathrm{m}^{-2}$ average in the control, laser, beta irradiations and longer exposure time to gamma, up to $480.1 \mathrm{~g} \mathrm{~m}^{-2}$ in other treatments. Seed priming by magnetic fields, ultrasonic waves and shorter exposure time to gamma irradiation can be effectively used to improve crop performance and yield, especially in late-sown plants.
\end{abstract}

Key words: chlorophyll, delayed sowing date, uniformity of emergence, ultrasonic wave.

\section{RESUMEN}

La siembra y buen establecimiento del cultivo y su efecto sobre el rendimiento es uno de los principales desafíos en la producción de cultivos. El objetivo de este trabajo es evaluar los tratamientos físicos en semilla de trigo que estimulen la germinación para el establecimiento del cultivo. El ensayo se realizó en Tabriz, Irán, entre abril y agosto durante 2013 y 2014, con dos fechas de siembra, 17 de abril y 2 de mayo. Para estimular la germinación de las semillas estas fueron sometidas a tratamientos de ultrasonido, láser, campos magnéticos y radiación gamma y beta por 3,5 y 5 min. Todas las semillas tratadas mejoraron el coeficiente de uniformidad, respecto de las no tratadas. El vigor de las plántulas mejoró significativamente con los tratamientos. No hubo diferencia significativa en las semillas tratadas con láser, gamma y beta respecto del tiempo de siembra a cosecha. Las semillas que fueron tratadas con campos magnéticos, ultrasonido y menor radación gamma concentraron más clorofila en las hojas. No hubo diferencia significativa entre los rendimientos de plantas sembradas con fecha 17 de abril y 2 de mayo. El rendimiento varió de $334 \mathrm{~g} \mathrm{m-2}$ promedio en el control, láser, radiaciones beta y gamma $5 \mathrm{~min}$; hasta 480,1 g m-2 promedio en el resto de los tratamientos. Los resultados sugieren que al tratar las semillas con campos magnéticos, ondas ultrasónicas y 3,5 min de exposición a radiación gamma mejora el rendimiento del cultivo de trigo.

Palabras clave: Clorofila, fecha de siembra diferido, la homogeneidad de la emergencia, la onda ultrasónica.

\section{Introduction}

Production of wheat (Triticum aestivum) in Iran was 7 million tons in 2012. Wheat-soybean agricultural systems cover about $25 \%$ of the total wheat area and $20 \%$ of the total soybean area in Iran. The farmers in the wheat-soybean zone of Tabriz in Iran principally grow semi-late maturing wheat varieties, and the occurrence of rain during land preparation may cause a delay of 2-3 weeks in sowing. Therefore, wheat yield harvest is generally delayed in most of the farms in this area. The late harvest coupled with poor soil structure creates problems for preparation of a good seedbed for soybean as a secondary crop (Allahyari 2013).

Good crop establishment and its effect on productivity is one of the major challenges in crop production; its importance is recognized by farmers

\footnotetext{
1 Department of Agronomy and Plant Breeding, Tabriz Branch, Islamic Azad University, Tabriz, Iran.

* Corresponding author: mirshekari@iaut.ac.ir
} 
as well as researchers (Chivasa et al., 1998). Seed priming has been found a doable technology to enhance rapid and uniform emergence, high vigor and better yields in crop species (Gupta and Hunsigi 2010). Physical priming of wheat seed may improve its emergence and growth (Basra et al., 2012). In an experiment conducted to explore the possibility of improving late sown wheat performance by seed priming techniques, seed emergence, stand establishment, allometry, grain yield and harvest index improved significantly. However, seed priming techniques did not affect plant height, number of spikelets or 1000 grain weight (Farooq et al., 2007). Ultrasonic irradiation led in early emergence; it shortened ripening time of vegetable crops by $5-10$ days (Aladjadjiyan 2002). Lower doses of gamma irradiation positively affected growth and seed yield of okra (Abelmoschus esculentus L.) over the control (Hejazi and Hamideldin 2010). Similarly, Dubey et al. (2007) showed that plant height and branches per plant increased when okra (Abelmoschus esculentus) seeds were irradiated with different doses of gamma rays. There is a little information about the influence of physical seed treatment methods on yield potential of cereal crops. The present study was conducted to study the possibility of improving the emergence, stand establishment and yield of late sown wheat by seed priming.

\section{Materials and Methods}

The experiments were conducted in Tabriz, Iran during 2013-2014. Tabriz (Lat. 38 ${ }^{\circ}, 5^{\prime}$; Long. $46^{\circ}$, $17^{\prime}$ and elevation $1360 \mathrm{~m}$ ) is located in northwestern
Iran; the climate is semi-arid. The experimental soil was sandy-loam with EC $0.74 \mathrm{ds} \mathrm{m}^{-1}, \mathrm{pH} 7.9$ and $0.81 \%$ organic matter. Some weather data in the experimental site during crop growth cycle are given in Table 1.

The experiments were laid out in a completely randomized design in a greenhouse and in a randomized complete block design in field conditions with three replicates; plot size was $6 \times 4 \mathrm{~m}^{2}$. Dry wheat seeds with $85 \%$ viability were differently treated by ultrasonication $(50-60 \mathrm{~Hz}, 1.5 \mathrm{~V})$, laser (He-Ne, IR 2000, 6328 A $^{\circ}, 220 \mathrm{~V}, 50 \mathrm{~Hz}$ ), magnetic field ( $40 \mathrm{mT}, 3 \mathrm{~A}, 2.7 \mathrm{~V}$ ), gamma and beta (Co60 and Sr90 2 microcurie) irradiation for 3.5 and 5 min. Seeds not receiving prior treatment served as control. Twenty five physically primed seeds for each treatment were placed in pots $(19 \times 21 \mathrm{~cm})$ containing farm soil under greenhouse conditions $\left(25 \pm 1^{\circ} \mathrm{C}\right)$ for an emergence test.

In greenhouse condition, the number of emerged seeds was recorded daily according to the seedling evaluation handbook of the Association of Official Seed Analysts. Final emergence percentage (FEP) was calculated as the cumulative number of germinated seeds with normal radicles using equation 1 , as described by Larsen and Andreasen (2004).

$\mathrm{FEP}=\Sigma \mathrm{n} / \mathrm{N} \times 100$

Equation (1)

where $\mathrm{n}$ is the number of germinated seeds at each counting and $\mathrm{N}$ is total seeds in each treatment. Time taken for $50 \%$ seedling emergence $\left(\mathrm{E}_{50}\right)$ was calculated according to the following formula of Coobear et al. (1984).

Table 1. Some weather data in the experimental site during the crop growth cycle.

\begin{tabular}{|c|c|c|c|c|}
\hline Year & Month & $\begin{array}{c}\text { Temperature } \\
\left({ }^{\circ} \mathrm{C}\right)\end{array}$ & $\begin{array}{l}\text { Precipitation } \\
(\mathrm{mm})\end{array}$ & $\begin{array}{l}\text { Relative humidity } \\
\qquad(\%)\end{array}$ \\
\hline \multirow{6}{*}{2013} & April & 20.3 & 38.5 & 62.0 \\
\hline & May & 27.9 & 21.0 & 60.3 \\
\hline & June & 31.9 & 3.5 & 32.7 \\
\hline & July & 28.1 & 3.0 & 30.7 \\
\hline & August & 16.1 & 14.0 & 69.2 \\
\hline & Total & - & 80.0 & - \\
\hline \multirow{6}{*}{2014} & April & 17.3 & 32.3 & 51.1 \\
\hline & May & 25.0 & 17.9 & 57.0 \\
\hline & June & 29.2 & 8.2 & 40.0 \\
\hline & July & 33.1 & 7.2 & 35.1 \\
\hline & August & 19.3 & 17.2 & 60.1 \\
\hline & Total & - & 82.8 & - \\
\hline
\end{tabular}


$\mathrm{E}_{50}=\mathrm{t}_{\mathrm{i}}+\left(\mathrm{N} / 2-\mathrm{n}_{\mathrm{i}}\right)\left(\mathrm{t}_{\mathrm{j}}-\mathrm{t}_{\mathrm{i}}\right) / \mathrm{n}_{\mathrm{j}}-\mathrm{n}_{\mathrm{i}}$

Equation (2)

where $\mathrm{N}$ is the final number of emerged seeds, and $n_{i}$ and $n_{j}$ are the cumulative number of seeds emerged in adjacent counts at times $\mathrm{t}_{\mathrm{i}}$ and $\mathrm{t}_{\mathrm{j}}$ when $\mathrm{n}_{\mathrm{i}}<\mathrm{N} / 2<\mathrm{n}_{\mathrm{j}}$. Mean emergence time (MET) was calculated according to the equation 3 (Ellis and Roberts 2001):

$\mathrm{MET}=\Sigma \mathrm{Dn} / \Sigma \mathrm{n}$

Equation (3)

where $\mathrm{n}$ is the number of seeds which emerged on day $\mathrm{D}$, and $\mathrm{D}$ is the number of days counted from the beginning of emergence. The coefficient of uniformity of emergence (CUE) was calculated using the formula of Bewley and Black (1985):

$\mathrm{CUE}=\Sigma \mathrm{n} / \Sigma[(\mathrm{t}-\overline{\mathrm{t}}) \times \mathrm{n}]$

Equation (4)

where $t$ is the time in days starting from day 0 , the day of sowing, $n$ is the number of seeds completing emergence on day $t$ and $\bar{t}$ is equal to MET. Seedling vigor index (SVI) was calculated according to Abdul-Baki and Anderson (1973) using equation 5.

\section{$\mathrm{SVI}=\mathrm{SDW} \times \mathrm{FEP}$}

Equation (5)

where, SDW is seedling dry weight.

In all plots, two cultivations with a tractor-drawn cultivator along with manuring $12 \mathrm{t} \mathrm{ha}^{-1}$ followed by a planking were done to achieve desirable soil structure. Then fields were plotted in the early spring before sowing. Seeds were hand sown on 17 April and 2 May in rows $15 \mathrm{~cm}$ apart at $4-5 \mathrm{~cm}$ depth. The seeding rate in the experiment was 120 $\mathrm{kg} \mathrm{ha}^{-1}$. Based on soil analysis, $\mathrm{P}$ and $\mathrm{K}$ fertilizers were applied basally at the rate of 85 and $20 \mathrm{~kg} \mathrm{ha}^{-1}$, respectively. Nitrogen was applied at the rate of 100 $\mathrm{kg} \mathrm{ha}^{-1} ; 50 \%$ was applied basally and the rest at the booting stage. Four time irrigations were given to all treatments until 20 days after pollination. Weeds were hand removed during the growing seasons. The seeds were harvested separately for each plot when spikes were fully ripened at approximately $20 \%$ moisture. In field condition, 75 days after emergence leaf area index (LAI) and chlorophyll content index (CCI) were determined. At harvesting time agronomic traits and yield components were estimated following standard procedures. Data were statistically analyzed using the software MSTAT-C. Analysis of variance was used to test the significance of variance sources, and LSD tests $(\mathrm{P}=0.05)$ were used to compare the differences among treatment means.

\section{Results and Discussion}

\section{Greenhouse experiment}

All of the seed priming techniques reduced the time to start emergence, $\mathrm{E}_{50}$ and MET compared to the control. Minimum time to start emergence, $\mathrm{E}_{50}$ and MET were found for ultrasonication, laser irradiation and magnetic field for both exposure times and only for the lower dose of gamma irradiation. Seeds treated with beta irradiation and longer exposure time to gamma had time to start emergence, $\mathrm{E}_{50}$ and MET statistically equal to the control (Table 2). All of the seed priming treatments also improved the CUE compared to non-primed seeds; however, maximum CUE was recorded in ultrasound and magnetic field treatments (Table 2). There have been a lot of studies recently on the invigoration of seeds (Coobear et al., 1984; Basra et al., 2012) that improves seed performance and provides faster and synchronized germination. The effect of the studied treatments on FEP was significant. The average FEP from magnetic field and ultrasound-primed seeds was nearly $94.6 \%$, but only $84.1 \%$ with laser, while beta and higher dose of gamma-primed seeds were statistically the same as the control (Table 2).

Maximum SDW ( $\left.0.79 \mathrm{~g} \mathrm{plant}^{-1}\right)$ was found in the magnetic field treatment for $5 \mathrm{~min}$, followed by magnetic field for $3.5 \mathrm{~min}$. and ultrasound treatments $\left(0.67 \mathrm{~g} \mathrm{plant}^{-1}\right)$, and the lowest from treatments of gamma, beta and control (Table 2). SVI responded positively and significantly to seed priming agents. The results show that SVI can be increased by seed priming with the same trend as observed above in SDW. The results suggest that reduction in exposure time to magnetic field from 5 to $3.5 \mathrm{~min}$. may reduce SVI. Non-vigorous seedling production was also reported for sweet pepper (Capsicum annum $\mathrm{L}$.) when higher dosages of magnetic field were used for seed priming (El-ebad and Abbas 2009). Besides, SVI of seeds treated with gamma and beta irradiation was found to be similar to the control. Seed priming has been shown to enhance speed of germination, reduce the time between sowing and emergence, improve seedling vigor, stand establishment and increase yield (Diniz et al., 2009). 
Table 2. Some studied traits in wheat crop as affected by seed priming techniques.

\begin{tabular}{lccccccc}
\hline Priming techniques & $\begin{array}{c}\text { Time to start } \\
\text { emergence (days) }\end{array}$ & $\begin{array}{c}\mathrm{E}_{50}{ }^{*} \\
\text { (days) }\end{array}$ & $\begin{array}{c}\text { MET } \\
\text { (days) }\end{array}$ & CUE & FEP & $\begin{array}{c}\text { SDW } \\
\left(\text { g.plant }^{-1}\right)\end{array}$ & SVI \\
\hline Ultrasound 3.5 min. & 5.00 & 11.1 & 13.0 & 0.85 & 96.0 & 0.68 & 65.3 \\
Ultrasound 5 min. & 5.00 & 11.5 & 13.1 & 0.92 & 94.8 & 0.64 & 60.7 \\
Laser 3.5 min. & 5.80 & 12.1 & 14.1 & 0.58 & 82.5 & 0.50 & 41.3 \\
Laser 5 min. & 5.81 & 12.4 & 14.3 & 0.53 & 84.0 & 0.50 & 42.0 \\
Magnetic field 3.5 min. & 4.49 & 11.0 & 13.5 & 0.91 & 94.0 & 0.69 & 64.9 \\
Magnetic field 5 min. & 4.51 & 11.0 & 13.6 & 0.91 & 93.6 & 0.79 & 73.9 \\
Gamma 3.5 min. & 5.80 & 11.8 & 13.6 & 0.63 & 86.0 & 0.48 & 41.3 \\
Gamma 5 min. & 7.41 & 13.5 & 17.2 & 0.63 & 87.5 & 0.45 & 39.4 \\
Beta 3.5 min. & 8.00 & 13.0 & 17.0 & 0.59 & 82.5 & 0.46 & 38.4 \\
Beta 5 min. & 7.52 & 13.8 & 16.8 & 0.59 & 82.0 & 0.48 & 39.4 \\
Control & 7.50 & 13.6 & 16.1 & 0.50 & 85.0 & 0.53 & 45.1 \\
LSD 5\% & 1.39 & 1.10 & 1.80 & 0.17 & 6.31 & 0.13 & 10.22 \\
\hline
\end{tabular}

$* \mathrm{E}_{50}$, MET, CUE, FEP, SDW and SVI mean time taken to 50\% seedling emergence mean emergence time, coefficient of uniformity of emergence, final emergence percentage, seedling dry weight and seedling vigor index of the crop plant respectively.

\section{Field experiment}

The weather conditions during the growing season in the years 2013 and 2014 were quite similar (Table 1). In a combined analysis of variance of the data there was no significant difference between data from the two years of experiment. Considering the similar temperatures and precipitation rates during the growing seasons of wheat in the present study, this result was not unexpected. Therefore, the averaged data from two years of experiment were compared.

For seeds sown on 17 April and 2 May, harvesting time in the plots treated under magnetic field and ultrasound occurred 100.6 and 87.8 days after sowing, respectively (Table 3 ). It appears that primed seeds are better able to complete the process of emergence in a short time and cope with probable environmental stresses. This early and uniform stand establishment enables the crop to complete other phenological events in crop ontogeny well in time (Kant et al., 2003). Gupta and Hunsigi (2010) reported that primed peppermint plants grew more vigorously, flowered earlier and yielded more. In the present study there was no significant difference between laser, gamma and beta irradiations in time from sowing to harvesting, and in all plots crop plants completed their growth period 104.8 days after sowing (Table 3 ). This study suggests that performance of the late sown plants can be improved by employing seed priming techniques. Previous studies showed that seed priming led to vigorous and faster emergence of seedlings, bestowing wideranging phenological and yield related benefits (Farooq et al., 2007).

Crop LAI of magnetic field and ultrasoundtreated seeds sown on 2 May improved similarly to those sown on 17 April; LAI was statistically unaffected due to a delay of 15 days in seed sowing. In the experiment, lower LAI (1.48) was observed for non-treated late sown seeds (Table 3). The results of our study indicated that magnetic field irradiation of seeds had a positive effect on growth of aboveground parts of wheat, which is in conformity with the reports of Aladjadjiyan and Ylieva (2002) in tobacco (Nicotiana tabaccum) and Atak et al. (2003) in soybean (Glycine max). Seedling growth and fresh weight could be increased by magnetic field treatment. Majd et al. (2010) reported that the common vetch (Vicia sativa L.) samples exposed to $1700 \mathrm{G}$ magnetic field for $20 \mathrm{~min}$. in wet conditions had maximum LAI compared to control.

Wheat seeds primed by magnetic fields, ultrasonic waves and shorter exposure time to gamma irradiation had high chlorophyll in leaves, and with increasing of exposure time of gamma irradiation from 3.5 to $5 \mathrm{~min}$. CCI was significantly restricted. Treatment of gamma irradiation for $3.5 \mathrm{~min}$. as well as magnetic field and ultrasound treatments produced heavier seeds with TSW of $50.5 \mathrm{~g}$, while TSW only averaged $40.5 \mathrm{~g}$ from other treatments including the control (Table 4). Rang and Radpir (2007) came to the same conclusion in their study on priming fennel seeds. 
Table 3. Time from sowing to harvesting and leaf area index of wheat as affected by priming techniques and sowing dates.

\begin{tabular}{|c|c|c|c|c|}
\hline \multirow{3}{*}{ Priming techniques } & \multicolumn{4}{|c|}{ Sowing date } \\
\hline & $17^{\text {th }}$ April & $2^{\text {th }}$ May & $17^{\text {th }}$ April & $2^{\text {th }}$ May \\
\hline & \multicolumn{2}{|c|}{ Time from sowing to harvesting (days) } & \multicolumn{2}{|c|}{ Leaf area index } \\
\hline Ultrasound $3.5 \mathrm{~min}$. & 99.7 & 89.0 & 2.95 & 3.0 \\
\hline Ultrasound 5 min. & 99.0 & 87.5 & 3.11 & 3.0 \\
\hline Laser $3.5 \mathrm{~min}$. & 103.0 & 101.3 & 2.65 & 2.7 \\
\hline Laser 5 min. & 103.0 & 102.9 & 2.65 & 2.7 \\
\hline Magnetic field $3.5 \mathrm{~min}$. & 103.5 & 89.5 & 3.03 & 3.0 \\
\hline Magnetic field $5 \mathrm{~min}$. & 100.0 & 85.0 & 2.99 & 3.1 \\
\hline Gamma 3.5 min. & 108.0 & 103.0 & 2.64 & 2.6 \\
\hline Gamma 5 min. & 107.0 & 103.0 & 2.70 & 2.6 \\
\hline Beta $3.5 \mathrm{~min}$. & 107.0 & 105.3 & 2.70 & 2.6 \\
\hline Beta 5 min. & 109.0 & 104.9 & 2.65 & 2.5 \\
\hline Control & 108.1 & 104.5 & 2.70 & 2.5 \\
\hline LSD $5 \%$ & 7.51 & 7.51 & 0.26 & 0.26 \\
\hline
\end{tabular}

Table 4. Chlorophyll content index, thousand seed weight and seed yield of wheat as affected by priming techniques.

\begin{tabular}{llll}
\hline Priming techniques & CCI $^{*}$ & TSW $(\mathrm{g})$ & $\begin{array}{l}\text { Seed yield } \\
\left(\mathrm{g} \mathrm{m}^{-2}\right)\end{array}$ \\
\hline Ultrasonic 3.5 min. & 41.5 & 50.0 & 530.3 \\
Ultrasonic 5 min. & 48.0 & 50.0 & 485.1 \\
Laser 3.5 min. & 32.0 & 41.0 & 300.4 \\
Laser 5 min. & 35.1 & 41.2 & 322.1 \\
Magnetic field 3.5 min. & 50.0 & 51.0 & 480.9 \\
Magnetic field 5 min. & 50.1 & 53.2 & 548.9 \\
Gamma 3.5 min. & 48.5 & 48.5 & 475.1 \\
Gamma 5 min. & 30.0 & 40.0 & 340.0 \\
Beta 3.5 min. & 32.1 & 40.3 & 353.1 \\
Beta 5 min. & 30.2 & 39.4 & 337.5 \\
Control & 30.0 & 41.0 & 350.9 \\
LSD 5\% & 6.90 & 7.11 & 76.21 \\
\hline
\end{tabular}

* CCI and TSW mean chlorophyll content index and thousand seed weight respectively.

There was no significant difference between seed yields from sowing dates of 17 April and 2 May; the yield ranged from $334 \mathrm{~g} \mathrm{~m}^{-2}$ average in the control, laser and beta irradiations and higher exposure time of gamma, up to $480.1 \mathrm{~g} \mathrm{~m}^{-2}$ in other treatments (Table 4). Magnetic fields are environmental factors that affect plants; magnetic field treatment of seed as reported by Aladjadjiyan )2007), Dhawi et al. (2009) and Vasilevski (2003( stimulates seed germination and improves the yield potential of crop plants. This also is in agreement with the results observed by DeSouza et al. (2006), who reported that the effect of magnetic field priming on yield and yield components of tomato was significantly positive. Gupta and Hunsigi (2010) concluded that different physical seed priming treatments in peppermint (Mentha piperita) seeds were the most effective to get maximum herb yield and net return in both varieties. Yaldagard et al. (2008) reported an increase in barley yield from ultrasound treatment of $6.53 \%$. This is probably due to increased FEP as a result of ultrasound treatment of seeds. It is also possible that the electrical and light energy (i.e. sonoluminescence effect) released by the cavitation effect produces physiological or biochemical changes in the seed which promote the germination process. Wheat seed priming by magnetic field, ultrasonic waves and shorter exposure time to gamma irradiation can be effectively used to improve the crop performance and yield, especially in late sown plants. 


\section{Acknowledgements}

The authors would like to offer particular thanks to the Seed Improvement Institute, Karaj Iran, for kindly providing the materials studied.
The corresponding author is also grateful to Prof. Hamdollah Kazemi Arbat, from the Department of Agronomy, University of Tabriz, Iran, for critically reviewing the manuscript.

\section{Literature Cited}

Abdul-Baki, A.A.; Anderson, J.D.

1973. Vigor determination in soybean by multiple criteria. Crop Science, 13: 630-633.

Aladjadjiyan, A.

2007. The use of physical methods for plant growing stimulation. Journal of Central European Agriculture, 8: 369-380.

Aladjadjiyan, A.; Ylieva, T.

2002. Influence of stationary magnetic field on the early stages of the development of tobacco seeds (Nicotiana tabacum

L.). Journal of Central European Agriculture, 4: 131-135.

Allahyari, $\mathrm{H}$.

2013. Alternating agricultural systems based on wheat in Iran. Ministry of Agriculture Press, East Azerbaijan, Iran.

Atak, C.; Emiroglu, O.; Alikamanoglu, S.; Rzakoulieva, A.

2003. Stimulation of regeneration by magnetic field in soybean (Glycine $\max$ L. Merrill) tissue cultures. Journal of Cell and Molecular Biology, 2: 113-119.

Basra, S.M.A.; Zia, M.N.; Mehmood, T.; Afzal, I.; Khaliq, A. 2012. Comparison of different invigoration techniques in wheat (Triticum aestivum L.) seeds. Pakistan Journal of Arid Agriculture, 5: 6-11.

Bewley, J.D.; Black, M.

1985. Seeds: Physiology of development and germination. Plenum Press, New York, USA.

Chivasa, W.; Harris, D.; Chiduza, C.; Mashingaidze, A.B. 1998. Agronomic practices, major crops and farmer's perceptions of the importance of good stand establishment in Musikavanhu communal area, Zimbabwe. Journal of Applied Science, 4: 9-25.

Coobear, S.; Verma, P.; Pahuja, S.S.

1984. Effect of seed priming on germination, phenology and growth of sorghum under late-sown conditions. Tropical Agricultural Science, 44: 9-15.

Desouza, A.; Garcí, D.; Sueiro, L.; Gilart, F.; Porras, E.; Licea, L. 2006. Pre-sowing magnetic treatments of tomato seeds increase the growth and yield of plants. Bioelectomagnetics, 27:247-257.

Dhawi, F.; Al-Khayri, J.M.; Hassan, E.

2009. Static magnetic field influence on elements composition in date palm (Phoenix dactylifera $\mathrm{L}$.). Research Journal of Agricultural and Biological Science, 5: 161-166.

Diniz, K.A.; Silva, P.A.; Oliveira, J.A., Evangelista, J.R.E.

2009. Sweet pepper seed responses to inoculation with microorganisms and coating with micronutrients, amino acids and plant growth regulators. Agricultural Science, 66: 293-297.

Dubey, A.K.; Yadav, J.R.; Singh, B.

2007. Studies on induced mutations by gamma irradiation in okra (Abelmoschus esculentus (L.) Monch.). Progressive Agriculture, 7: 46-48.
El-Ebad, M.; Abbas, R.

2009. Sweet pepper seed responses to different doses of magnetic field. Egyptian Journal of Medicinal Plants, 19 (4): 111-116.

Ellis, R.A.; Roberts, E.H.

2001. The quantification of ageing and survival in orthodox seeds. Seed Science and Technology, 9: 373-409.

Farooq, M.; Basra, S.M.A.; Rehman, H.; Saleem, B.A.

2007. Seed priming enhances the performance of late sown wheat (Triticum aestivum L.) by improving chilling tolerance. Journal of Agronomy and Crop Science, 194: 55-60.

Gupta, T.; Hunsigi, S.L.

2010. Improving the performance of peppermint (Mentha piperita) by physical seed priming under semi-arid conditions. Indian Journal of Medicinal Plants Research, Special Issue: $15-21$.

Hejazi, A.Z.; Hamideldin, N.

2010. The effect of gamma irradiation on enhancement of growth and seed yield of okra (Abelmoschus esculentus L.) and associated molecular changes. Journal of Horticulture and Forestry, 2 (3): 38-51.

Kant, S.; Verma, P.; Pahuja, S.S.

2003. Growth and yield maintenance in bread wheat by seed priming under late-sown conditions. Acta Agronomica Hungriana, 51: 445-453.

Larsen, S.U.; Andreasen, C.

2004. Light and heavy turf-grass seeds differ in germination percentage and mean germination thermal time. Crop Science, 44: 1710-1720.

Majd, A.; Farzpourmachiani, S.; Dorranian, D.

2010. Evaluation of the effect of magnetic fields on seedling ontogenesis and growth of vetch (Vicia sativa L.). Journal of Plant Science Research, 5: 8-17.

Rang, J.; Radpir, R.

2007. Fennel (Foeniculum vulgare) yield components responses to seed priming with physical agents. Indian Journal of Plant Science, 8 (1): 123-128.

Vasilevski, G.

2003. Perspectives of the application of biophysical methods in sustainable agriculture. Bulgarian Journal of Plant Physiology, Special Issue: 179-186.

Yaldagard, M.; Mortazavi, S.A.; Tabatabaie, F.

2008. Application of ultrasonic waves as a priming technique for accelerating and enhancing the germination of barley seed: optimization of method by the Taguchi approach. Journal of Institute Brewing, 22: 22-27. 